\title{
Glucocorticoids Rapidly Inhibit Oxytocin-Stimulated Adrenocorticotropin Release from Rat Anterior Pituitary Cells, Without Modifying Intracellular Calcium Transients*
}

\author{
HEIKE LINK, GOVINDAN DAYANITHI†, AND MANFRED GRATZL
}

Abteilung Anatomie und Zellbiologie, Universität Ulm (H.L., M.G.), D-7900 Ulm, Germany; and Laboratoire de Neurobiologie Endocrinologique (G.D.), Unité de Recherche Associée 1197-Centre National de la Recherche Scientifique, Université de Montpellier II, F-34095 Montpellier Cedex 5, France

\begin{abstract}
Glucocorticoid hormones suppress the secretion of ACTH evoked by secretagogues such as CRF and arginine vasopressin. In this study we investigated the effects of glucocorticoids on ACTH release induced by oxytocin (OT) and on intracellular free calcium ion levels in corticotropes prepared from the adenohypophyses of female Wistar rats.

Pulsatile additions of physiological concentration of OT (10 nM) to superfused anterior pituitary cells caused pulsatile ACTH release about 4 -fold above basal secretion with similar peak amounts of ACTH during subsequent OT pulses. Exposure of the cells to corticosterone (100 nM) or to a selective glucocorticoid receptor agonist RU $28362(100 \mathrm{nM})$ for 30 min suppressed OT-stimulated but not basal ACTH release by approximately $60 \%$. Inhibition gradually disappeared during subsequent pulses of $\mathrm{OT}$ in the absence of corticosterone. Pretreatment with
\end{abstract}

the selective antagonist RU $38486(1 \mu \mathrm{M})$ completely blocked the inhibitory effect of corticosterone on OT-induced ACTH secretion. Changes in free cytosolic calcium levels in single cultured pituitary cells were measured using the calcium indicator Fura-2. OT caused calcium transients in corticotropes, which were identified by immunocytochemistry. They responded in a similar manner to a second $\mathrm{O}^{\prime} \mathrm{T}$ stimulus when preincubated for $30 \mathrm{~min}$ with corticosterone $(1 \mu \mathrm{M})$ or with RU $28362(1 \mu \mathrm{M})$. Our data indicate that glucocorticoids, via glucocorticoid receptors, rapidly inhibit OT-stimulated ACTH secretion by corticotropes without affecting intracellular calcium transients due to OT. Therefore, we conclude that rapid inhibition of $\mathrm{ACTH}$ release by glucocorticoids interferes with cellular signal transduction beyond the step of calcium mobilization. (Endocrinology 132: 873-878, 1993)
$I^{T}$ IS well established that the secretion of ACTH by anterior pituitary corticotrope cells is stimulated by hypothalamic neurohormones, such as CRF or arginine vasopressin (AVP) (1), and is suppressed by adrenal glucocorticoid hormones (2). Several lines of evidence support the notion that oxytocin $(\mathrm{OT})$ is involved in the regulation of pituitary ACTH secretion; it is present in high concentrations in rat hypophysial portal blood $(3,4)$, and high affinity receptors for OT have been identified in the rat pituitary (5). Recently, we have demonstrated that physiological concentrations of OT added in pulsatile fashion to isolated rat pituitary cells stimulate ACTH secretion, independent of other ACTH secretagogues (6). OT may therefore function as a hypophysiotropic hormone contributing to physiological regulation of ACTH release by the hypothalamus. In addition, we showed that OT, like AVP and CRF, causes rises in free cytosolic calcium levels in corticotropes, suggesting that calcium transients play

Received July 30, 1992

Address all correspondence and requests for reprints to: Dr. Govindan Dayanithi, Laboratoire de Neurobiologie Endocrinologique, Université de Montpellier II, Place Eugene Bataillon, F-34095 Montpellier Cedex 5 , France.

* This work was supported by Deutsche Forschungsgemeinschaft Gr681, Landesforschungsschwerpunkt Molekulare Grundlagen der zellulären Differenzierung, Musterbildung und Morphogenese and grants from the Association National de la Recherche Technique France (PROCOPE 92126), Fonds der Chemischen Industrie, and from the Graduierten-Kolleg "Biomolekulare Medizin" (Ulm, Germany).

$\dagger$ Fellow of the Alexander von Humboldt-Stiftung, Germany. the key role to trigger ACTH secretion (7-9). Indeed, studies with permeabilized cell preparations indicate that calcium is the main trigger substance in controlling exocytosis in exo crine $(10,11)$ and endocrine cells $(12-15)$, including a corticotropic tumor cell line (16).

Glucocorticoid feedback inhibition of stimulated ACTH secretion comprises several time domains (17). Acute suppression is evident within less than one hour of glucocorticoid administration, but the mechanism of the inhibitory action is unknown. In earlier studies (18-20) it was shown that a brief (20-40 $\mathrm{min})$ exposure to corticosterone strongly inhibited ACTH secretion evoked by CRF or AVP. This inhibitory effect was fully antagonized by the glucocorticoid/ progestin-antagonist RU 38486, indicating that it is exerted through glucocorticoid receptors (21).

There have been inconsistent reports using a mouse pituitary tumor cell line (AtT-20) regarding glucocorticoid effects on CRF-induced transients in intracellular calcium. In a recent study (22) it was reported that intracellular calcium signals due to CRF stimulation are suppressed by glucocorticoid hormones. But, using the same model, no change in intracellular calcium transients in the presence of glucocorticoids was recently reported (23). In order to understand the action of glucocorticoids on ACTH release and on intracellular calcium levels within normal pituitary corticotropes, we examined in the present study: 1) whether OT-induced ACTH secretion is inhibited by glucocorticoids; and 2) whether glucocorticoids modify transients in free cytosolic calcium levels triggered by OT. 


\section{Materials and Methods}

\section{Perifusion of isolated rat anterior pituitary cells}

The experimental procedures employed in this study have previously been described $(21,24)$ with necessary modifications (6). Briefly, dispersed rat anterior pituitary cells were prepared by tryptic digestion from the adenohypophyses of female Wistar rats $(250-350 \mathrm{~g}$ body wt; obtained from Charles River Wiga GmbH, Sulzfeld, Germany). The cells were mixed with preswollen Sephadex G-10 (Pharmacia, Uppsala, Sweden) and transferred to perifusion columns (volume $0.4 \mathrm{ml}$ ) which were then perifused at $37 \mathrm{C}$ with $22 \mathrm{~mm}$ HEPES-buffered ( $\mathrm{pH}$ 7.4) Dulbecco's minimal essential medium (Flow Laboratories, Irvine, Scotland) containing $0.25 \%$ (wt/vol) BSA (fraction V, Miles Laboratories, Elkhart, IN) and antibiotic-antimycotic drugs (Sigma, Deisenhofen, Germany). After an equilibration period of $2 \mathrm{~h}$, various treatments were applied. OT was given every $30 \mathrm{~min}$ for a 5 -min period. Glucocorticoid receptor agonists (corticosterone, RU 28362) were applied $25 \mathrm{~min}$ before the application of the second OT stimulus and were also included in the medium during the second exposure to OT. Glucocorticoid receptor antagonist (RU 38486) was given $35 \mathrm{~min}$ before the second OT stimulus and was also present during exposure to corticosterone and $\mathrm{OT}$. The synthetic steroids RU 28362, a selective glucocorticoid receptor agonist (25) and RU 38486, a glucocorticoid/progestin antagonist (26) were generously supplied by Roussel Uclaf (Romainville, France). Steroids were dissolved in dimethylsulfoxide (DMSO; Sigma, Deisenhofen, Germany) and diluted in perifusion medium to the desired dilution. The final concentration of DMSO in the perifusion medium did not exceed $0.001 \%$.

Two-minute fractions of the column effluents were collected during the experimental period and assayed for ACTH content by RIA (27) using antiserum AS 6 (courtesy of G. B. Makara, Institute of Experimental Medicine, Hungarian Academy of Sciences, Budapest, Hungary). Purified human $\mathrm{ACTH}_{1-39}$ (Sigma) was used as the standard. Data are reported as net ACTH release standardized within each cell column. The reference values taken as $100 \%$ are given in the figure legends. Data are expressed as the mean \pm SEM. Statistical evaluation was performed by two-way nonparametric analysis of variance, followed by Student's two-tailed unpaired $t$ test.

\section{Primary cultures of pituitary cells}

Pituitary cells were prepared as described previously (6). Aliquots of cell suspensions were plated in poly-L-lysine-coated plastic petri dishes with Dulbecco's modified Eagle's medium (Biochrom KG, Berlin, Germany) buffered with $26 \mathrm{~mm}$ sodium bicarbonate, pH 7.0, containing 20 mм cytosin- $\beta$-D-arabino-furanoside and $10 \%$ fetal calf serum and incubated in a humidified atmosphere $\left(5 \% \mathrm{CO}_{2} / 95 \%\right.$ air) at $37 \mathrm{C}$ for $3-5$ days. The medium was changed after $24 \mathrm{~h}$ and subsequently every 48 h,

\section{Measurement of intracellular free calcium levels}

The procedures used to measure intracellular free calcium levels in single cells have been described (6). Briefly, the culture dish was washed with serum-free medium, and the cells were loaded with Fura-2/AM (Calbiochem, La Jolla, CA; $1.5 \mu \mathrm{m}$ final concentration, $0.1 \% \mathrm{DMSO}$ ) for $30 \mathrm{~min}$ at $37 \mathrm{C}$. The cells were then washed with modified Locke medium (140 mM NaCl, $4.7 \mathrm{mM} \mathrm{KCl}, 1 \mathrm{~mm} \mathrm{CaCl}, 1.2 \mathrm{mM} \mathrm{KH}_{2} \mathrm{PO}_{4}, 1.2$ $\mathrm{mm} \mathrm{MgSO}_{4}, 0.5 \mathrm{~mm}$ ascorbic acid, $11 \mathrm{~mm}$ glucose, $15 \mathrm{~mm}$ piperazine$N, N^{\prime}$-bis(2-ethanesulfonic acid), buffered to $\mathrm{pH} 7.2$ with $\mathrm{NaOH}$ ). The same medium was used for calcium measurements. The cells were then subjected to fluorescence measurements with a Zeiss microscope photometer system (FFP, Zeiss, Oberkochen, Germany) up to $2 \mathrm{~h}$ after dye loading. The system is based on an inverted microscope (Axiovert $405 \mathrm{M}$ ) equipped for epifluorescence, and interference filters of $340 / 10 \mathrm{~nm}$ and $380 / 10 \mathrm{~nm}$ are alternatively mounted on the filter wheel. The ratio calculations $r=$ F340/F380 were carried out according to Grynkiewicz et al. (28).

Randomly selected cells from the culture dish were treated with an OT stimulus and recorded for $2 \mathrm{~min}$. Responding cells were video printed. The cells were then washed twice and were incubated with corticosterone $(1 \mu \mathrm{M})$ or RU $28362(1 \mu \mathrm{M})$ for $25 \mathrm{~min}$. The same cells were then subjected to a second OT stimulus in the presence of the steroid. After the calcium measurements, corticotropes were identified among the mixed cell population in the primary cultures by immunocytochemistry as described below.

\section{Immunocytochemistry of pituitary corticotropes in primary culture}

After the calcium measurements, the cells were fixed in cold paraformaldehyde ( $4 \%$ in $10 \mathrm{~mm}$ PBS, $\mathrm{pH} 7.2$ ) for $30 \mathrm{~min}$ and incubated with anti-ACTH antiserum (courtesy of K. Kovacs, Institute of Experimental Medicine, Hungarian Academy of Sciences, Budapest, Hungary; final dilution 1:2000) overnight at $4 \mathrm{C}$. Antigen-antibody complexes were visualized by the double antibody avidin-biotin-peroxidase complex technique as described earlier (6). Antiserum specificity and method specificity were performed by omitting the primary antiserum and incubations with respective buffer or incubations with normal rabbit serum (1:2000). A coordinate system within the FFP allowed identification of cells previously analyzed for calcium transients.

\section{Results}

\section{$A C T H$ release by $O T$ and inhibition by corticosterone}

The kinetics of ACTH release due to OT were first examined with a concentration of the stimulating agent similar to that found in rat portal blood. Figure 1A shows the ACTH release by dispersed perifused rat anterior pituitary cells caused by five subsequent pulses of $10 \mathrm{~nm}$ OT. Successive applications of OT every $30 \mathrm{~min}$ for a 5 -min period released similar amounts of ACTH up to $3 \mathrm{~h}$. During the experimental period, basal ACTH release was approximately $1-2 \%$ (15 \pm $5 \mathrm{fmol} / 2$-min fraction) of the total release and remained nearly constant throughout the experiment.

Application of corticosterone at $100 \mathrm{~nm}$ for $25 \mathrm{~min}$ before and 5 min during the second OT stimulus suppressed ACTH release elicited by O'T by approximately $60 \%$ (Fig. 1B). Basal ACTH release was not affected. The effect of corticosterone within this 30 -min time domain was marked and statistically significant $(P<0.05)$. This effect of corticosterone was almost completely reversed within $180 \mathrm{~min}$ of subsequent OT addition in the absence of further corticosterone application. Stimulation of ACTH release by higher doses of OT $(10 \mu \mathrm{M})$ was inhibited by corticosterone $(100 \mathrm{~nm})$ to a similar extent as that observed with $10 \mathrm{~nm}$ OT. In these experiments, after exposure to corticosterone at $100 \mathrm{nM}$ (similar experimental protocol as in Fig. 1B) the release of ACTH was inhibited by $67 \%$ at the second OT stimulus and $48 \%, 27 \%$, and $21 \%$ during subsequent pulses of OT (mean of two experiments). Furthermore, pituitary cells from primary cultures (4 days) were loaded into perifusion columns, and a similar corticosterone treatment as in Fig. 1 was applied. This experimental paradigm is important in order to compare the measurements of changes in intracellular calcium levels from primary cell cultures in the absence or presence of glucocorticoid hormones. Interestingly, we did not observe any difference in the net ACTH response due to OT (data not shown), and the inhibition by $100 \mathrm{~nm}$ corticosterone of OT-induced ACTH release was $35 \%$ at the second OT stimulus and $32 \%, 21 \%$, and $7 \%$ during subsequent pulses of OT.

\section{Effect of glucocorticoid agonists and antagonists on OT-induced ACTH release}

The net ACTH release due to OT in the presence or absence of various glucocorticoids is shown in Figs. 2 and 3. 
FIG. 1. Release of ACTH by perifused rat anterior pituitary cells in response to subsequent pulses of $10 \mathrm{nM}$ OT (A) and the effect of $100 \mathrm{nM}$ corticasterone on this process (B). Perifused cells were exposed to $100 \mathrm{nM}$ corticosterone for 25 min as indicated by the bar (GC); the black bars show application of $10 \mathrm{nM}$ OT for $5 \mathrm{~min}$ every $30 \mathrm{~min}$. Data are ex. pressed as percentage of total amount of $\mathrm{AC}$ TH detected in all fractions assayed. The control experiment (A) represents the values from a single column run at the same time with other columns, where the cells were exposed to steroids simultaneously. The points represent means, and the bars show SEM; $\mathrm{n}=3$. The effect of corticosterone (B) was significant ( $P$ $<0.05) 25 \mathrm{~min}, 60 \mathrm{~min}$, and $90 \mathrm{~min}$ after steroid application.
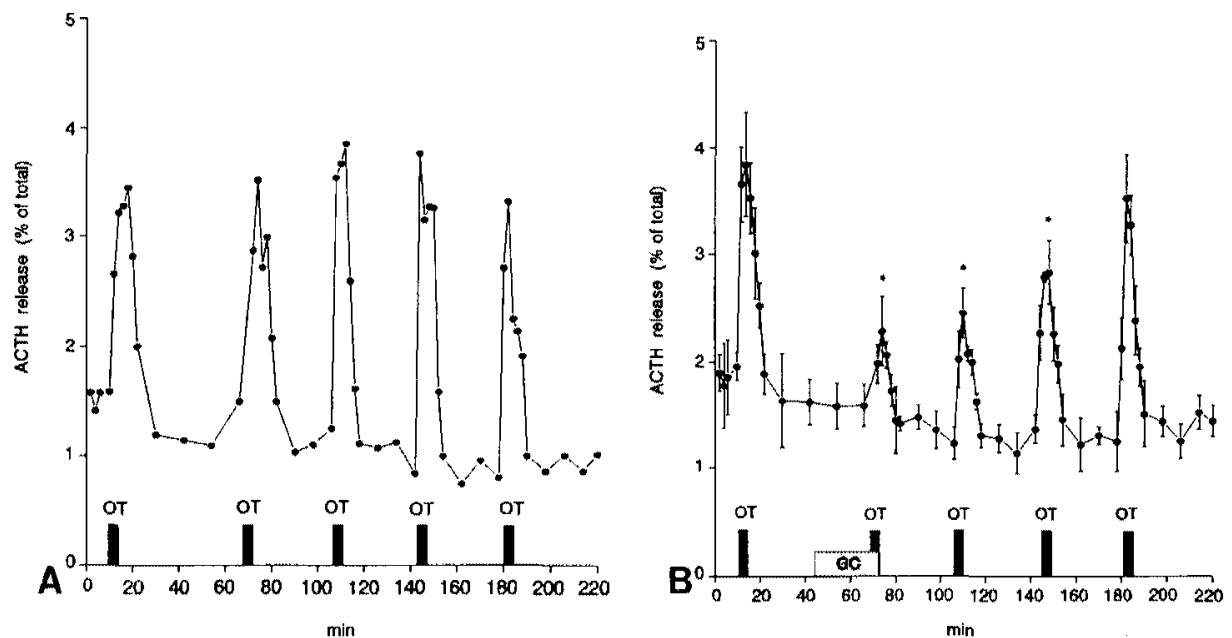

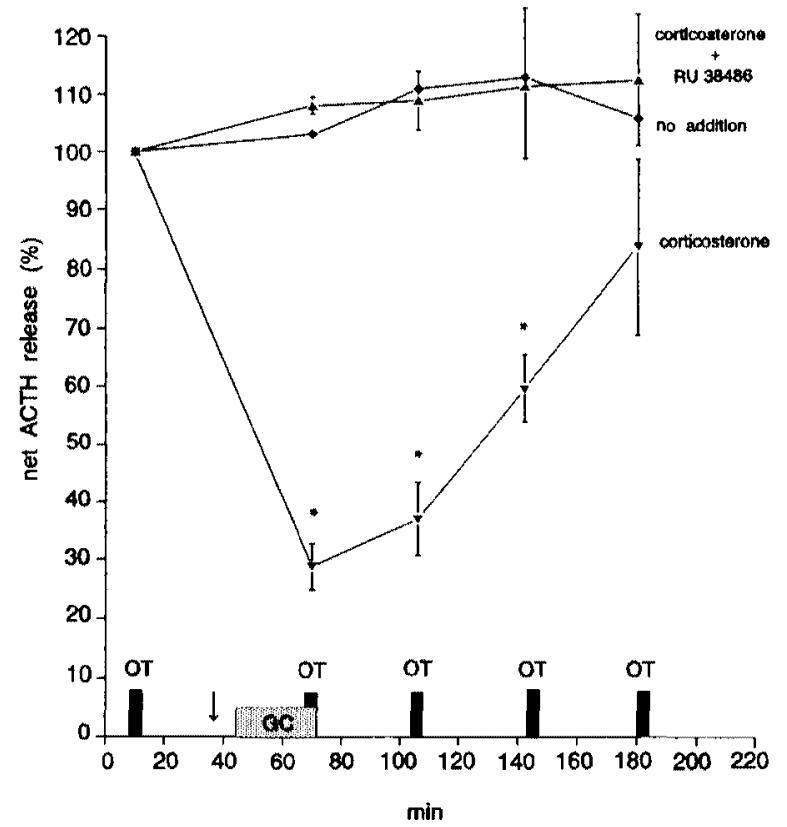

Fig. 2. Effect of $100 \mathrm{~nm}$ corticosterone and antagonism by RU 38486 $(1 \mu \mathrm{M})$ on OT-induced ACTH release. Data are expressed as percentage of the net amount of ACTH release of the first control exposure to 10 nM OT (range, 42-88 fmol $/ 10 \mathrm{~min}$ ). The points are means, and the bars show the SEM. RU 38486 was given $10 \mathrm{~min}$ before corticosterone application (arrow) and was also present during the 25 min of corticosterone application (GC). The black bars show application of OT at 10 $\mathrm{nM}$ for $5 \mathrm{~min}$. Note that the data of the corticosterone experiment correspond to Fig. 1B. * $P<0.05$ when compared to control group ( $\bullet$ ).

The glucocorticoid/progestin receptor antagonist RU 38486 $(1 \mu \mathrm{M})$ completely blocked the inhibitory action of corticosterone (Fig. 2). In this experiment, RU 38486 was present 10 min before and also included into the perifusion medium during the $25-\mathrm{min}$ application of corticosterone before the second OT challenge. The corticosterone effect was antagonized throughout the experimental period.

In order to further characterize the glucocorticoid effect on OT-stimulated ACTH release, the cells were exposed for $25 \mathrm{~min}$ to the highly selective glucocorticoid receptor agonist RU 28362 at a concentration of $100 \mathrm{nM}$. RU 28362 potently

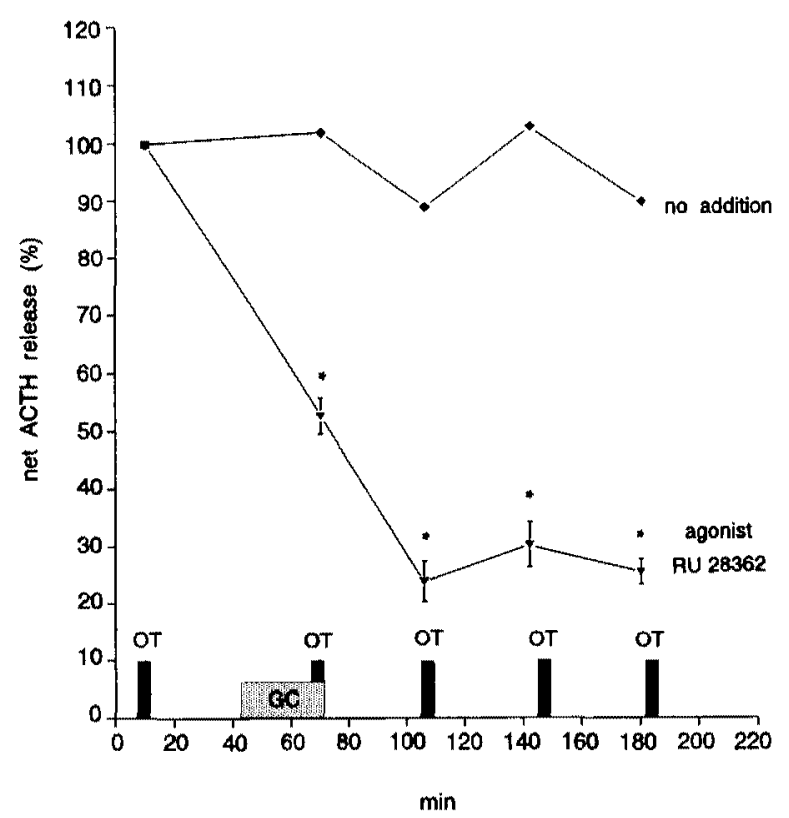

FIG. 3. Effects of glucocorticoid agonist RU $28362(100 \mathrm{nM})$ on ACTH release induced by $10 \mathrm{nM} O \mathrm{OT}$. RU 28362 (GC) was present $25 \mathrm{~min}$ before and 5 min during the second OT stimulus. The $100 \%$ value is the net ACTH release in response to the first OT stimulus applied (range, 40-90 $\mathrm{fmol} / 10 \mathrm{~min}$ ). The control experiment ( $\bullet$ ) was run with the same cell preparation. The glucocorticoid agonist effect was significant $(P<0.05)$ at all following OT stimuli. The points are the means of three individual experiments; the bars show the SEM.

suppressed OT-induced ACTH release by $80 \%$, and this inhibition persisted for $2 \mathrm{~h}$ (Fig. 3).

Transients in intracellular free calcium levels due to OT in the absence or presence of corticosterone or RU 28362

Cytoplasmic calcium levels were analyzed in cultures from several different pituitary cell preparations and more than 200 cells were investigated in this study. They were stimulated individually with $100 \mathrm{nM} \mathrm{OT}$, and intracellular calcium levels were recorded for a 2 -min period. The values given below represent data for OT-responsive and identified corticotropes. 
In unstimulated corticotropes the basal calcium levels were stable and ranged from $70-100 \mathrm{~nm}(\mathrm{n}=21$ corticotropes out of 225 examined cells). As already observed in our previous study (6), $100 \mathrm{~nm}$ OT increased the cytosolic free calcium concentrations in identified corticotropes (Figs. 4A and 5A). Figure $4 \mathrm{~B}$ shows a representative calcium transient in 1 of 6 immunocytochemically identified corticotropes, which was then incubated for 25 min with $1 \mu \mathrm{M}$ corticosterone followed by a second $100 \mathrm{nM}$ OT stimulus. In Fig. 5B, a similar experiment is shown using $1 \mu \mathrm{M}$ RU 28362. Five identified corticotropes responded in the same way in the presence of the glucocorticoid agonist. Note that a similar protocol was followed in secretion studies where the cells were exposed to steroids for $25 \mathrm{~min}$ before and $5 \mathrm{~min}$ during OT stimulation. In all cells analyzed, the OT-induced intracellular calcium transients were not substantially different when the steroids were present.

\section{Discussion}

The regulation of adenohypophyseal ACTH secretion is complex and involves multiple regulatory factors of hypothalamic, neurohypophyseal, and peripheral origins. Among the stimuli that elicit ACTH from pituitary corticotropes are
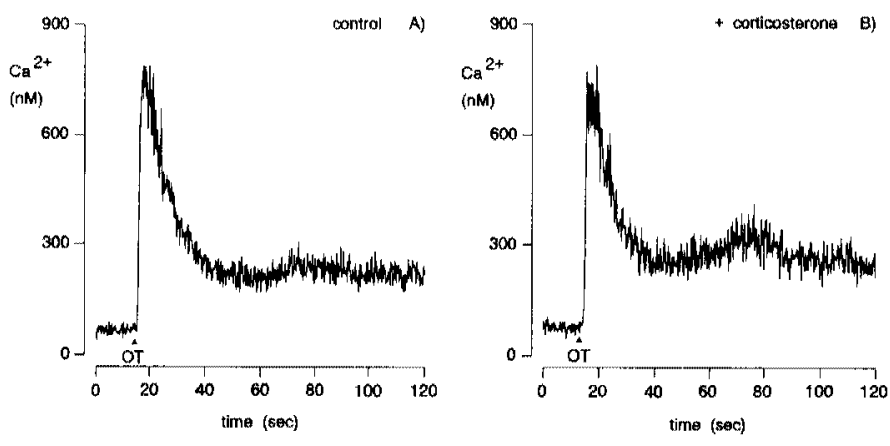

FIG. 4. Rise of OT-induced intracellular calcium in a single immunocytochemically identified corticotrope in the absence or presence of corticosterone. Intracellular calcium concentration rapidly increases by a challenge with OT (100 nM) (A). After washing and preincubating the cells with $1 \mu \mathrm{M}$ corticosterone for $25 \mathrm{~min}$, the OT-responding cells were challenged with a second $\mathrm{OT}$ stimulus (B). Arrowheads indicate additions of $O T$. The profiles shown are representative of six cells treated in the same manner.
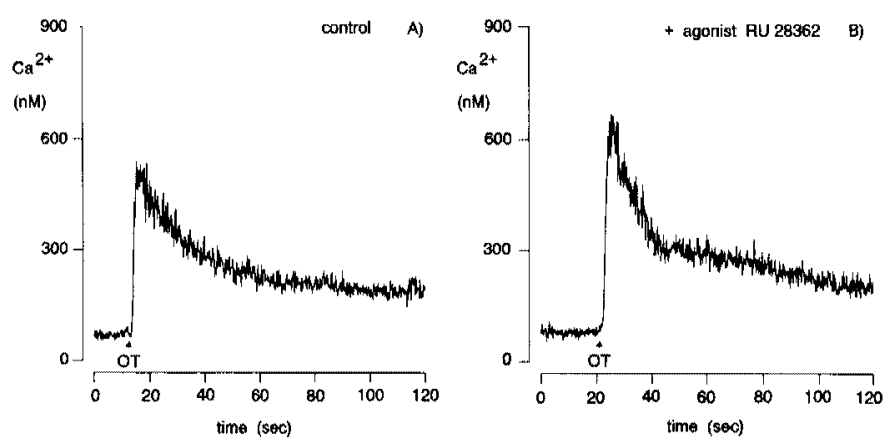

FIG. 5. Intracellular calcium levels in response to OT (100 nM) in the absence or presence of RU 28362. A similar experimental protocol was followed as described in Fig, 4. The glucocorticoid agonist RU 28362 (1 $\mu \mathrm{M}$ ) was present $25 \mathrm{~min}$ before the second $\mathrm{O}^{\mathrm{T}} \mathrm{stimulus.}$ Arrowheads indicate additions of OT. The profiles shown are representative of five cells treated in the same manner.
CRF and AVP (for review see Ref. 1). Recently, OT was shown to be an effective secretagogue of ACTH secretion: when applied in pulsatile fashion, it induces ACTH release by isolated pituitary corticotropes dose dependently and independent of the presence of CRF or AVP (6). An increase of intracellular calcium by mobilizing calcium mainly from intracellular stores appears to be the basic mechanism of OT action leading to ACTH secretion.

As is generally accepted, increases in cytosolic free calcium result in the release of hormones or neurotransmitters by exocytosis $(12-15,29,30)$. Such increase in intracellular calcium are brought about by calcium influx through the plasma membrane and/or release of calcium from intracellular stores (for review see Ref. 31). AVP causes the breakdown of phosphoinositides and formation of inositol 1,4,5trisphosphate $\left(\mathrm{IP}_{3}\right)$ and diacylglycerol in dispersed rat anterior pituitary cells (32). $\mathrm{IP}_{3}$ causes an increase in cytosolic calcium by evoking its release from intracellular stores from many different types of cells including endocrine cells (33, 34). Experimental evidence reported by different groups, that is secretion studies in the presence or absence of extracellular calcium or direct measurements of calcium transients in corticotropes exposed to OT or AVP $(6,9,35,36)$, emphasizes the involvement of intracellular calcium stores during $\mathrm{ACTH}$ release. On the other hand, CRF causes influx of extracellular calcium through calcium channels, and these influxes are secondary to CRF-stimulated cAMP production $(8,37,38)$. It has been proposed that calcium channels in a variety of cells are activated by CAMP $(39,40)$. A study with permeabilized corticotrope tumor cells (AtT-20) provides evidence for requirement of calcium and no direct effect of CAMP on exocytotic release of ACTH (16). Thus, it can be concluded that intracellular calcium is the main regulatory substance, which triggers ACTH release from corticotropes irrespective of the secretagogues. However, as outlined above, the calcium sources are different: signal pathways for AVP and OT lead to mobilization of calcium mainly from intracellular stores, whereas CRF stimulation leads to calcium influx.

It is well documented that inhibition of ACTH secretion is exerted by glucocorticosteroids from the adrenal cortex, which constitutes the negative feedback loop of the hypothalamo-pituitary-adrenocortical axis. Three types of time domains of the inhibitory action-rapid, delayed, and slow suppression-can be distinguished, and the rapid inhibitory action was proposed to be an effect on the secretory process (17). Although POMC gene down-regulation by glucocorticoids has been observed within $15 \mathrm{~min}$, an acute reversible change in the amounts of translated ACTH available for release in corticotropes is not likely $(41,42)$. The rapid inhibition by glucocorticoids of CRF- or AVP-induced ACTH release is well documented $(18,21,43,44)$. The present investigation demonstrates the rapid inhibition by glucocorticoids of OT-stimulated ACTH secretion. The time course (suppression is evident within $30 \mathrm{~min}$ ) as well as the degree of inhibition $(60 \%)$ is consistent with previous findings with other secretagogues $(19,45)$. The independence of rapid inhibition of the secretagogue used to stimulate ACTH release and therefore of the intracellular pathways, which lead to elevation of cytosolic calcium, suggests a common mechanism of the glucocorticoid effect. In addition, our results 
imply that rapid inhibition of OT-induced ACTH release by glucocorticoids, similar to the release induced by CRF or AVP in earlier studies (21), is mediated through glucocorticoid receptors.

In contrast to a previous study (35), where $2 \mathrm{~h}$ dexamethasone-pretreated adenohypophyseal cells were exposed to a single stimulus (10 min), we observed during pulsatile applications of secretagogues a pronounced effect of glucocorticoids on the peak of ACTH released. In addition, the short exposure $(30 \mathrm{~min})$ to corticosterone or glucocorticoid agonist and antagonist indicate the potency and specificity of the steroid effects on ACTH secretion due to pulsatile application of secretagogues. Such an experimental procedure is closer to conditions in vivo, as evident from previous work demonstrating the rhythmic activity of oxytocinergic neurons in the paraventricular nucleus (46) and pulsatile release of OT into the circulation (47).

However, the mechanism of rapid glucocorticoid inhibition on stimulated ACTH secretion is still unclear. In our previous study (6), we showed direct evidence that OT-induced ACTH secretion implies mobilization of calcium from intracellular stores. Our present results clearly demonstrate that the inhibitory effect of glucocorticoid on OT-induced ACTH secretion is not exerted through changes in intracellular calcium levels, since neither glucocorticoid (corticosterone or RU 28362) exhibits an effect on the OT-induced calcium transients. In a previous study it was shown that AVP-induced calcium rise was also not altered by the presence of dexamethasone from normal pituitary cell suspension (48). Since neither the kinetics of the OT-induced calcium transient onset nor the height of the peak were affected by the presence of glucocorticoids in the present study, we conclude that cytosolic calcium transients induced by OT are not affected by glucocorticoids, suggesting that glucocorticoids may not inhibit $\mathrm{IP}_{3}$-mediated calcium release from intracellular stores. Furthermore, $\mathrm{IP}_{3}$ production induced by physiological concentrations of AVP in anterior pituitary fragments is not inhibited by glucocorticoids within the rapid time domain $(49,50)$. These data suggest an effect of glucocorticoids on a step further downstream in the stimulussecretion coupling process, i.e. beyond stimulus-induced calcium mobilization from intracellular stores.

The reports on glucocorticoid effects on CAMP production are controversial: An alteration of CRF-induced increases of cAMP levels by glucocorticoids was proposed $(49,51)$ and refuted $(23,52,53)$. The latter studies, which support an effect of glucocorticoids beyond the rise of cAMP, are in accordance with secretion studies using permeable analogs of cAMP $(20,54)$.

Studies using the clonal pituitary cell line AtT-20 also provide contradictory results regarding the glucocorticoid effect on CRF-induced intracellular calcium increase. A suppression of CRF-induced calcium transients was shown (22), whereas in another study no effect of glucocorticoids on intracellular calcium rise was found (23). A direct effect of glucocorticoids on stabilization of actin filaments was suggested as a possible mechanism (23). However, the slow time course for any rearrangement of the cytoskeleton $(2 \mathrm{~h})$ does not correspond to the rapid glucocorticoid inhibition of $\mathrm{ACTH}$ release by OT, CRF, and AVP reported in the present and previous studies $(21,44)$.

Taken together, we provide direct evidence that OT-induced ACTH secretion is inhibited by glucocorticoids rapidly and that the immediate inhibitory action does not alter OTinduced calcium transients in corticotropes. We conclude that the inhibitory action on exocytotic ACTH release is mediated through glucocorticoid receptors and is exerted beyond the step of intracellular calcium increase.

\section{Acknowledgments}

The authors thank Ulrike Fröhlich for her skillful technical assistance, Prof. G. B. Makara and Dr. K. Kovacs for ACTH antisera, Prof. R. Steger (Department of Physiology, University of Illinois, Carbondale, IL), Prof. I. Assenmacher (Laboratoire de Neurobiologie Endocrinologique, Université de Montpellier-2, Montpellier, France), and Dr. D. Pow (Department of Physiology and Pharmacology, University of Queensland, Queensland, Australia) for critical reading of the manuscript. We are grateful to Zeiss (Oberkochen, Germany) for providing the equipment for calcium measurements.

\section{References}

1. Antoni FA 1986 Hypothalamic control of adrenocorticotropin secretion: advances since the discovery of 41-residue corticotropinreleasing factor. Endocr Rev 7:351-378

2. Jones MT, Gillham B 1988 Factors involved in the regulation of adrenocorticotropic hormone/ $\beta$-lipotropic hormone. Physiol Rev 68:743-818

3. Sapolsky RM, Armanini MP, Packan DR, Sutton SW, Plotsky PM 1990 Glucocorticoid feedback inhibition of adrenocorticotropic hormone secretagogue release. Neuroendocrinology 51:328-336

4. Fink G, Robinson ICAF, Tannahill LA 1988 Effects of adrenalectomy and glucocorticoids on the peptides CRF-41, AVP, and oxytocin in rat hypophysial portal blood. J Physiol 401:329-345

5. Antoni FA 1986 Oxytocin receptors in rat adenohypophysis: evidence from radioligand binding studies. Endocrinology 119:23932395

6. Link H, Dayanithi G, Föhr KI, Gratzl M 1992 Oxytocin at physiological concentrations evokes adrenocorticotropin $(\mathrm{ACTH})$ release from corticotrophs by increasing intracellular free calcium mobilized mainly from intracellular stores. Oxytocin displays synergistic or additive effects on ACTH-releasing factor or arginine vasopressininduced ACTH secretion, respectively. Endocrinology 130:21832191

7. Guérineau N, Corcuff J-B, Tabarin A, Mollard P 1991 Sponta neous and corticotropin-releasing factor-induced cytosolic calcium transients in corticotrophs. Endocrinólogy 129:409-420

8. Won JGS, Orth DN 1990 Roles of intracellular and extracellular calcium in the kinetic profile of adrenocorticotropin secretion by perifused rat anterior pituitary cells. I. Corticotropin-releasing factor stimulation. Endocrinology 126:849-857

9. Won JGS, Oki Y, Orth DN 1990 Roles of intracellular and extracellular calcium in the kinetic profile of adrenocorticotropin secretion by perifused rat anterior pituitary cells. II. Arginine vasopressin, oxytocin, and angiotensin-II stimulation. Endocrinology 126:858868

10. Stecher B, Ahnert-Hilger $G$, Weller U, Kemmer TP, Gratzl M 1992 Amylase release from streptolysin O permeabilized pancreatic acinar cells. Effects of calcium, GTPyS, cAMP, tetanus toxin and botulinum A toxin. Biochem J 283:899-904

11. Knight DE, Koh E 1984 Calcium and cyclic nucleotide dependence of amylase release from isolated pancreatic acinar cells rendered permeable by intense electric fields. Cell Calcium 5:401-418

12. Ahnert-Hilger G, Bhakdi S, Gratzl M 1985 Minimal requirements for exocytosis. A study using PC 12 cells permeabilized with staphylococcal alpha-toxin. J Biol Chem 260:12730-12734

13. Ronning SA, Martin TFJ 1986 Characterization of $\mathrm{Ca}^{2+}$-stimulated secretion in permeable $\mathrm{GH}_{3}$ pituitary cells. J Biol Chem 261:78347839

14. Ahnert-Hilger G, Gratzl M 1988 Controlled manipulation of the cell interior by pore-forming proteins. Trends Pharmacol Sci 9:195- 
197

15. Knight DE, Scrutton MC 1986 Gaining access to the cytosol: the technique and some applications of electropermeabilization. Biochem J 234:497-506

16. Luini A, De Matteis MA 1988 Dual regulation of ACTH secretion by guanine nucleotides in permeabilized AtT-20 cells. Cell Mol Neurobiol 8:129-138

17. Keller-Wood ME, Dallman MF 1984 Corticosteroid inhibition of ACTH secretion. Endocr Rev 5:1-24

18. Vale W, Vaughan J, Smith M, Yamamoto G, Rivier J, Rivier C 1983 Effects of synthetic ovine corticotropin-releasing factor, glucocorticoids, catecholamines, neurohypophysial peptides, and other substances on cultured corticotropic cells. Endocrinology 113:11211131

19. Antoni FA, Dayanithi G 1990 Evidence for distinct glucocorticoid and guanine $3^{\prime}, 5^{\prime}$-monophosphate-effected inhibition of stimulated adrenocorticotropin release in vitro. Endocrinology 126:1355-1360

20. Abou-Samra AB, Catt KJ, Aguilera G 1986 Biphasic inhibition of adrenocorticotropin release by corticosterone in cultured anterior pituitary cells. Endocrinology 119:972-977

21. Dayanithi G, Antoni FA 1989 Rapid as well as delayed inhibitory effects of glucocorticoid hormones on pituitary adrenocorticotropic hormone release are mediated by type II glucocorticoid receptors and require newly synthesized messenger ribonucleic acid as well as protein. Endocrinology 125:308-313

22. Antoni FA, Hoyland J, Woods MD, Mason WT 1992 Glucocorticoid inhibition of stimulus-evoked adrenocorticotrophin release caused by suppression of intracellular calcium signals. J Endocrinol 133:R13-R16

23. Castellino F, Heuser J, Marchetti S, Bruno B, Luini A 1992 Glucocorticoid stabilization of actin filaments: a possible mechanism for inhibition of corticotropin release. Proc Natl Acad Sci USA 89:3775-3779

24. Gillies G, Lowry PJ 1978 Perfused rat isolated anterior pituitary cell column as bioassay for factor(s) controlling release of adrenocorticotropin: validation of a technique. Endocrinology 103:521-527

25. Philibert D, Moguilewsky M, RU 28362: a useful tool for the characterization of glucocorticoid and mineralocorticoid receptors. Program of the 65th Annual Meeting of The Endocrine Society, San Antonio, TX, 1983, p 335 (Abstract)

26. Philibert D 1984 RU 38486: an original multifaceted antihormone in vivo. In: Agarwal MK (ed) Adrenal Steroid Antagonism. Walter de Gruyter \& $\mathrm{Co}$, New York, pp 77-101

27. Antoni FA, Holmes MC, Jones MT 1983 Oxytocin as well as vasopressin potentiate ovine CRF in vitro. Peptides 4:411-415

28. Grynkiewicz G, Poenie M, Tsien RY 1985 A new generation of calcium indicators with greatly improved fluorescence properties. J Biol Chem 260:3440-3450

29. Leong DA 1991 A model for intracellular calcium signaling and the coordinate regulation of hormone biosynthesis, receptors and secretion. Cell Calcium 12:255-268

30. Cazalis M, Dayanithi G, Nordmann JJ 1987 Requirements for hormone release from permeabilized nerve endings isolated from rat neurohypophyses. J Physiol 390:71-91

31. Almers W 1990 Exocytosis. Annu Rev Physiol 52:607-624

32. Raymond V, Leung PCK, Veilleux R, Labrie F 1985 Vasopressin rapidly stimulates phosphatidic acid-phosphatidylinositol turnover in rat anterior pituitary cells. FEBS Lett 182:196-200

33. Berridge MJ, Irvine RF 1989 Inositol phosphates and cell signalling Nature 341:197-205

34. Föhr KJ, Scott J, Ahnert-Hilger G, Gratzl M 1989 Characterization of the inositol 1,4,5-trisphosphate-induced calcium release from permeabilized endocrine cells and its inhibition by decavanadate and p-hydroxymercuribenzoate. Biochem J 262:83-89

35. Oki Y, Peatman TW, Qu Z-C, Orth DN 1991 Effects of intracellular calcium depletion and glucocorticoid on stimulated adrenocortico- tropin release by rat anterior pituitary cells in a microperifusion system. Endocrinology 128:1589-1596

36. Leong DA 1988 A complex mechanism of facilitation in pituitary ACTH cells: recent single-cell studies. J Exp Biol 139:151-168

37. Childs GV, Marchetti C, Brown AM 1987 Involvement of sodium channels and two types of calcium channels in the regulation of adrenocorticotropin release. Endocrinology 120:2059-2069

38. Labrie F, Veilleux R, Lefevre G, Coy DH, Sueiras-Diaz J, Schally AV 1982 Corticotropin-releasing factor stimulates accumulation of adenosine $3^{\prime}, 5^{\prime}$-monophosphate in rat pituitary corticotrophs. Science 216:1007-1008

39. Luini A, Lewis D, Guild S, Corda D, Axelrod J 1985 Hormone secretagogues increase cytosolic calcium by increasing cAMP in corticotropin-secreting cells. Proc Natl Acad Sci USA 82:8034-8038

40. Armstrong D, Eckert R 1987 Voltage-activated calcium channels that must be phosphorylated to respond to membrane depolarization. Proc Natl Acad Sci USA 84:2518-2522

41. Eberwine JH, Roberts IL 1984 Glucocorticoid regulation of proopiomelanocortin gene transcription in the rat pituitary. J Biol Chem 259:2166-2170

42. Drouin J, Trifiro MA, Plante RK, Nemer M, Eriksson P, Wrange Ö 1989 Glucocorticoid receptor binding to a specific DNA sequence is required for hormone-dependent repression of pro-opiomelanocortin gene transcription. Mol Cell Biol 9:5305-5314

43. Fleischer $\mathbf{N}$, Vale $\mathbf{W} 1968$ Inhibition of vasopressin-induced ACTH release from the pituitary by glucocorticoids in vitro. Endocrinology 83:1232-1236

44. Phillips M, Tashiian Jr AH 1982 Characterization of an early inhibitory effect of glucocorticoids on stimulated adrenocorticotropin and endorphin release from a clonal strain of mouse pituitary cells. Endocrinology 110:892-900

45. Widmaier EP, Dallman MF 1984 The effects of corticotropinreleasing factor on adrenocorticotropin secretion from perifused pituitaries in vitro: rapid inhibition by glucocorticoids. Endocrinology $115: 2368-2374$

46. Arey BJ, Freeman ME 1992 Activity of oxytocinergic neurons in the paraventricular nucleus mirrors the periodicity of the endogenous stimulatory rhythm regulating prolactin secretion. Endocrinology 130:126-132

47. Gilbert CL, Jenkins $K$, Wathes DC 1991 Pulsatile release of oxytocin into the circulation of the ewe during oestrus, mating and the early luteal phase. J Reprod Fertil 91:337-346

48. Knepel W, Schöfl C 1987 Intracellular free calcium concentration in rat anterior pituitary cells as indicated by fura-2: effect of argininevasopressin. Arch Pharmacol 336:321-326

49. Nicholson SA, Gillham B 1989 Glucocorticoids act rapidly in vitro to attenuate second messenger responses to ACTH secretagogues in rats. J Endocrinol 122:545-551

50. Bilezikjian LM, Blount AL, Vale WW 1987 The cellular actions of vasopressin on corticotrophs of the anterior pituitary: resistance to glucocorticoid action. Mol Endocrinol 1:451-458

51. Bilezikjian LM, Vale WW 1983 Glucocorticoids inhibit corticotropin-releasing factor-induced production of adenosine $3^{\prime}, 5^{\prime}$-monophosphate in cultured anterior pituitary cells. Endocrinology 113:657-662

52. Giguère V, Labrie F, Côte I, Coy DH, Sueiras-Diaz I, Schally AV 1982 Stimulation of cyclic AMP accumulation and corticotropin release by synthetic ovine corticotropin-releasing factor in rat anterior pituitary cells: site of glucocorticoid action. Proc Natl Acad Sci USA 79:3466-3469

53. Kant GJ, Mougey EH, Brown AJ, Meyerhoff JL 1989 Dexametha. sone suppresses ACTH release without attenuating pituitary cyclic AMP response to stress in vivo. Life Sci 45:125-131

54. Bilezikjian LM, Vale WW 1987 Regulation of ACTH secretion from corticotrophs: the interaction of vasopressin and CRF. Ann New York Acad Sci 512:85-96 